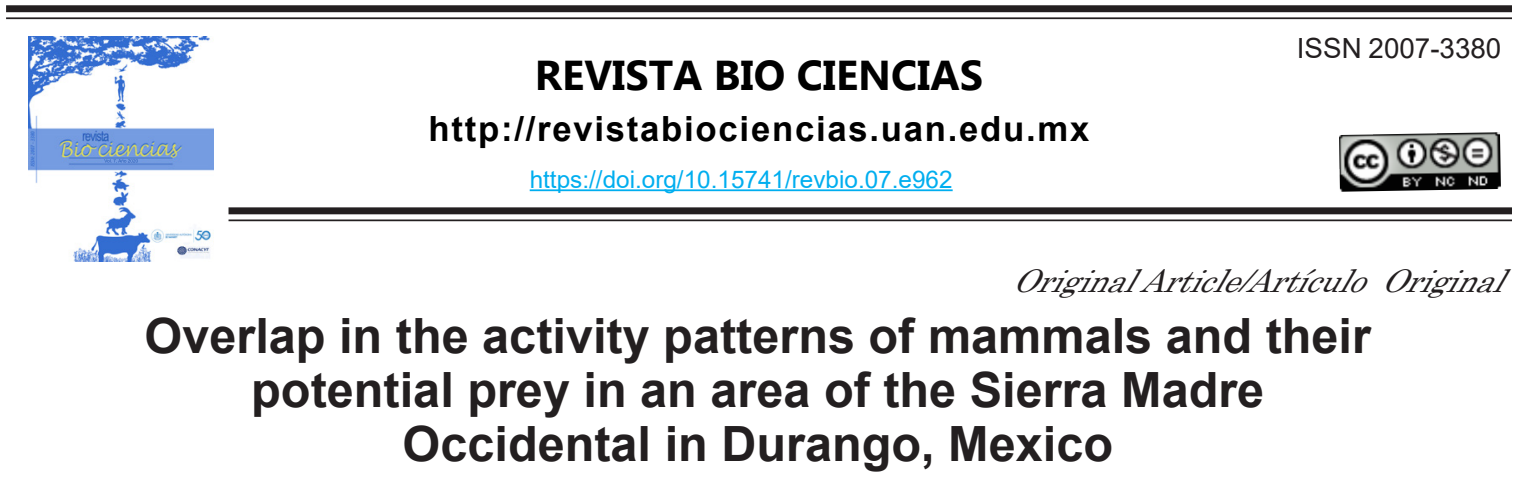

\title{
Solapamiento en los patrones de actividad de mamíferos y sus presas potenciales en un área de la Sierra Madre Occidental en Durango, México
}

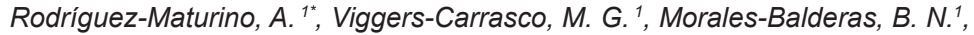 \\ López-Reyes, J. A. ${ }^{1}$, Silva-Flores, R. ${ }^{2}$, De León-Mata, G. D. ${ }^{1}$ \\ ${ }^{1}$ Tecnológico Nacional de México, Campus Valle del Guadiana. Carretera Durango-México km 22.5, \\ C.P. 34371, Villa Montemorelos. Durango, México. ${ }^{2}$ Consultora Forestal Durango, S. de R.L. \\ de C.V. Monte Cóndor 101, C.P. 34287, Durango. Durango, México.
}

Cite this paper/Como citar este artículo: Rodríguez-Maturino, A., Viggers-Carrasco, M. G., Morales-Balderas, B. N., López-Reyes, J. A., Silva-Flores, R., De León-Mata, G. D. (2020). Overlap in the activity patterns of mammals and their potential prey in an area of the Sierra Madre Occidental in Durango, Mexico. Revista Bio Ciencias 7, e962. doi: https://doi.org/10.15741/revbio.07.e962

A B S T R A C T

Ecological interactions are a fundamental part of ecosystem functioning, so investigating them can render information on the ecological balance in an area. This study aimed to estimate the relative abundance index (RAI) and determine potential interactions between mammals and their potential prey through photo-trapping in the Sierra del Nayar property, Durango. From August 2016 to May 2017, camera traps were placed during the rainy and dry season. From the photo records, the RAI, activity patterns by species, and the index of predator-prey overlap or competition among predators were estimated. Thirteen mammal species and Meleagris gallopavo were recorded. There were

Article Info/Información del artículo

Received/Recibido: March $27^{\text {th }} 2020$.

Accepted/Aceptado: October $22^{\text {th }} 2020$.

Available on line/Publicado: November $02^{\text {nd }} 2020$.
RES U M E N

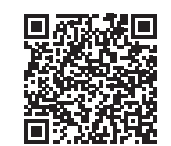

\section{${ }^{*}$ Corresponding Author:}

Alberto Rodríguez Maturino. Tecnológico Nacional de México, Campus Valle del Guadiana. Carretera Durango-México km 22.5, C.P. 34371, Villa Montemorelos. Durango, México. Phone: (618) 596 3051. E-mail: alberto.rm@vguadiana.tecnm.mx. http://www. itvalledelguadiana.edu. $\mathrm{mxl}$ 
no significant intra-specific differences in RAls between the rainy and dry seasons for any species. There were significant interspecific differences in RAls during the study period, the rainy season and the dry season. The most abundant species during the study period were: Odocoileus virginianus, M. gallopavo, Sciurus aberti, and Canis latrans. The five species from which their activity pattern was obtained presented a uniform distribution of data. The overlap index of six interactions was estimated, from which Urocyon cinereoargenteusSylvilagus floridanus and $C$. latrans-U. cinereoargenteus had the highest overlap index and did not present significant differences in their activity patterns. The activity patterns obtained are consistent with those reported for the species in North America.

\section{KEY WORDS}

Camera traps, predators, competition, Sierra del Nayar, Durango.

\section{Introduction}

The Sierra Madre Occidental (SMO) mountain complex is not only economically important but also biologically important, being an area of high biodiversity and endemism in Mexico (González-Elizondo et al., 2012; Martínez-Guerrero et al., 2018). Therefore, it is necessary to ensure the conservation and sustainable use of the natural resources of this ecosystem.

Among the different wildlife taxa distributed in the SMO, mammals are characterized as good indicators of the state of conservation of ecosystems due to their sensitivity to some alterations caused by man (Gittleman et al., 2001; Ojeda et al., 2003). Information on mammal diversity and abundance is important from a conservation standpoint since some can be used as umbrella species, and their study can help understand the effects of deforestation, fragmentation, loss of key species, and the impact of hunting (Laurance et al., 2000; Wright, 2000). The mammal group plays a very important role in the functioning of ecosystems, since they take part in various processes such as seed dispersal, herbivory, and pollination, as well as acting as predators and prey (Sinclair, 2003). virginianus, M. gallopavo, Sciurus aberti y Canis latrans. Las cinco especies de las que se obtuvo su patrón de actividad presentaron una distribución uniforme de los datos. Se estimó el índice de solapamiento de seis interacciones, de las cuales Urocyon cinereoargenteus-Sylvilagus floridanus y C. latrans- $U$. cinereoargenteus tuvieron el más alto índice de solapamiento y no presentaron diferencias significativas en sus patrones de actividad. Los patrones de actividad obtenidos concuerdan con lo reportado para las especies en Norteamérica.

\section{PALABRAS CLAVE}

Cámaras trampa, depredadores, competencia, Sierra del Nayar, Durango.

\section{Introducción}

El complejo montañoso de la Sierra Madre Occidental (SMO) tiene no solo importancia económica, sino biológica, al ser un área de alta biodiversidad y endemismos en México (González-Elizondo et al., 2012; Martínez-Guerrero et al., 2018). Por lo anterior, es necesario asegurar la conservación y aprovechamiento sustentable de los recursos naturales de este ecosistema.

Entre los diferentes taxones de fauna silvestre que se distribuyen en la $\mathrm{SMO}$, los mamíferos se caracterizan por ser buenos indicadores del estado de conservación de los ecosistemas debido a su sensibilidad a algunas alteraciones causadas por el hombre (Gittleman et al., 2001; Ojeda et al., 2003). La información sobre diversidad y abundancia de mamíferos es importante desde el punto de vista de la conservación, ya que algunas pueden ser usadas como especies sombrilla, además de que su estudio puede ayudar a entender los efectos de la deforestación, la fragmentación, la pérdida de especies clave y el impacto de la cacería (Laurance et al., 2000; Wright, 2000). El grupo de mamíferos cumple un papel muy importante en el funcionamiento de los ecosistemas, ya que participan en diversos procesos como la dispersión de semillas, la herbivoría y la polinización, además de actuar como depredadores y presas (Sinclair, 2003).

La técnica de fototrampeo es una herramienta que ha sido utilizada ampliamente en estudios de mamíferos (excepto roedores y quirópteros) en los últimos años (Mandujano, 2019). Se ha demostrado que esta técnica es una de las 
The photo-trapping technique is a tool that has been widely used in mammal studies (except for rodents and chiropters) in recent years (Mandujano, 2019). It has been demonstrated that this technique is one of the most efficient and proper for the evaluation of wildlife conservation status (Silveira et al., 2003). The use of camera traps compared to conventional methods has allowed for efficient estimation of parameters such as the richness and diversity of some groups such as felines and canids (Botello et al., 2008).

In Mexico, the photo-trapping technique has been used mainly for the study of medium and large mammals in the southeast of the country. The studies that have been carried out range from inventories to the estimation of environmental parameters such as diversity, relative abundance, and activity patterns in different terrestrial ecosystems. One of the most relevant aspects of the use of camera traps is the registration of species that are difficult to observe (Balme et al., 2009).

It has been determined that ecological interactions such as competition and predation affect population dynamics, influence abundance and distribution, and even the evolution of species (Begon et al., 2006). Within ecological dynamics are temporal aspects, those that have to do with how species distribute their activities throughout the day. The activity patterns of species can give information about their ecological niche. Species can show plasticity in their behavior, so factors such as deforestation and competing or invasive predatory species can alter these patterns of activity (Schoener, 1974; Frey et al., 2017).

The first studies of mammals in the state of Durango began with explorations in the central and southern regions of the state. Subsequent research has allowed the registration of not only new species but the expansion of their distribution (Ramirez-Muñoz et al., 2012; Gomez-Valenzuela et al., 2017). There is an updated registry of the mammals present in the state (García-Mendoza \& López-González, 2013).

Ecological studies on mammals in Durango have focused on the La Michilía Biosphere Reserve (LMBR) and the Mapimí Biosphere Reserve (MBR) and adjacent areas. On aspects of diet, Servin \& Huxley (1991) and Grajales-Tam et al. (2014) conclude that mammals are the main source of food for Canis latrans in both más eficientes y apropiadas para la evaluación del estatus de la conservación de la vida silvestre (Silveira et al., 2003). El uso de cámaras trampa comparado con el uso de métodos convencionales, ha permitido estimar de manera eficiente parámetros como la riqueza y diversidad de algunos grupos como felinos y cánidos (Botello et al., 2008).

En México, la técnica de fototrampeo se ha empleado principalmente para el estudio de mamíferos medianos y grandes en el sureste del país. Los estudios que se han efectuado abarcan desde inventarios, hasta la estimación de parámetros ecológicos como diversidad, abundancia relativa y patrones de actividad en diferentes ecosistemas terrestres. Uno de los aspectos más relevantes del uso de cámaras trampa es el registro de especies difíciles de observar (Balme et al., 2009).

Se ha determinado que interacciones ecológicas como la competencia y la depredación afectan la dinámica de las poblaciones, influyen en la abundancia y distribución, incluso en la evolución de las especies (Begon et al., 2006). Dentro de la dinámica ecológica se encuentran los aspectos temporales, aquellos que tiene que ver en como las especies se distribuyen sus actividades a lo largo del día. Los patrones de actividad de las especies pueden brindar información sobre su nicho ecológico. Las especies pueden mostrar plasticidad en su conducta, por lo que factores como la deforestación y especies competidoras o depredadoras invasoras, pueden alterar dichos patrones de actividad (Schoener, 1974; Frey et al., 2017).

Los primeros estudios de mamíferos en el estado de Durango iniciaron con exploraciones en la región central y sur del estado. Posteriores investigaciones han permitido registrar no solo nuevas especies, sino la ampliación de su distribución (Ramírez-Muñoz et al., 2012; GómezValenzuela et al., 2017). Se cuenta con un registro actualizado de los mamíferos del estado (García-Mendoza \& López-González, 2013).

Los estudios ecológicos sobre mamíferos en Durango se han centrado en la Reserva de la Biosfera La Michilía (LMBR) y la Reserva de la Biosfera Mapimí (MBR) y áreas adyacentes. En aspectos de dieta, Servín \& Huxley (1991) y Grajales-Tam et al. (2014) concluyen que los mamíferos son la principal fuente de alimento de Canis latrans en ambas reservas. Se ha estudiado el uso de hábitat de Sylvilagus audubonii y Lepus californicus en cinco asociaciones vegetales de la MBR (Arroyo-Rodríguez, 2005). Sobre 
reserves. The habitat use of Sylvilagus audubonil and Lepus californicus has been studied in five plant associations in the MBR (Arroyo-Rodríguez, 2005). The home range of Urocyon cinereoargenteus was found to have a preference for pine-oak forests in the LMBR (Servín et al., 2014). In a transition area of the SMO, Aragón et al. (2009) conducted a study on rodent assembly, they found four common species in pine-oak, oak-pine and grassland forests. Camera traps have been used as complementary tools for the elaboration of mammal inventories in the Sierra del Sarnoso (RamírezMuñoz et al., 2012) and MBR (Elizalde-Arellano et al., 2014). From this last research, 15 of the 31 species registered were detected by photo-trapping.

The studies that have been published on photo-trapping in the SMO are limited to a study conducted in the state of Chihuahua in coniferous forests in association with broad-leaved. They made comparisons between species abundance considering the rainy and dry seasons of 2013 and 2014 (Medina-Torres et al., 2015). The aim of this research was to estimate the relative abundance, as well as to find the potential interactions that can occur mainly in mammal species in the Sierra del Nayar (SN), Durango.

\section{Material and Methods}

\section{Study area}

The study was conducted in an area of temperate forest located in $\mathrm{SN}\left(23^{\circ} 34^{\prime} 6.3^{\prime \prime} \mathrm{N}, 105^{\circ} 1^{\prime} 5.5^{\prime \prime} \mathrm{W}\right)$, with an area of 16,482 ha. It is located in the municipality of Durango, with a maximum altitude of $2,648 \mathrm{~m}$, with pine and pine-oak forest vegetation (Figure 1).

The climate is temperate or mesothermal (C), presenting a dry winter $(\mathrm{Cw})$, the extreme temperatures are $36{ }^{\circ} \mathrm{C}$ and $-18{ }^{\circ} \mathrm{C}$. It presents an annual average precipitation of $1,300 \mathrm{~mm}$, with rain regime in the months of June to September, the first frosts can occur in October. In the months of December and January, there is snowfall (CONABIO, 2017).

\section{Photo-trapping}

Mammal monitoring was conducted over 10 months (August 2016 to May 2017) using the photo-trapping technique. Five sampling zones were established in the study area, and seven camera traps were placed in each one. During the rainy season el ámbito hogareño de Urocyon cinereoargenteus se concluyó que tiene preferencia por los bosques de pinoencino en la LMBR (Servín et al., 2014). En un área de transición de la SMO, Aragón et al. (2009) realizaron un estudio sobre ensamble de roedores, encontraron cuatro especies comunes en bosques de pino-encino, encinopino y pastizal. Cámaras trampa han sido empleadas como herramientas complementarias para la elaboración de inventarios de mamíferos en la Sierra del Sarnoso (Ramírez-Muñoz et al., 2012) y MBR (Elizalde-Arellano et al., 2014). De esta última investigación, 15 de las 31 especies registradas fueron detectadas por fototrampeo.

Los estudios que se han publicado sobre fototrampeo en la SMO se limitan a un estudio efectuado en el estado de Chihuahua en bosques de coníferas en asociación con latifoliadas. Realizaron comparaciones entre la abundancia de las especies considerando las temporadas de lluvias y secas de 2013 y 2014 (Medina-Torres et al., 2015). El objetivo de la presente investigación fue estimar la abundancia relativa, así como determinar las interacciones potenciales que pueden presentarse principalmente en especies de mamíferos en el predio Sierra del Nayar (SN), Durango.

\section{Material y Métodos}

\section{Área de estudio}

El estudio se llevó a cabo en un área de bosque templado situada en SN (23 $34^{\prime} 6.3^{\prime \prime} \mathrm{N}, 1^{\circ} 1^{\circ}$ ' 5.5” O), con una superficie de 16,482 ha. Se ubica en el municipio de Durango, con una altitud máxima de 2,648 msnm, con vegetación de bosque de pino y pino-encino (Figura 1).

El clima es templado o mesotermal (C), presentando un invierno seco $(\mathrm{Cw})$, las temperaturas extremas son de 36 ${ }^{\circ} \mathrm{C}$ y de $-18{ }^{\circ} \mathrm{C}$. Presenta una precipitación media anual de $1,300 \mathrm{~mm}$, con régimen de lluvias en los meses de junio a septiembre, las primeras heladas pueden ocurrir en octubre. En los meses de diciembre y enero se registran nevadas (CONABIO, 2017).

\section{Fototrampeo}

Se realizó un monitoreo de mamíferos durante un periodo de 10 meses (agosto de 2016 a mayo de 2017) con la técnica de fototrampeo. En el área de estudio se establecieron cinco zonas de muestreo, en cada una se colocaron siete cámaras trampa. Durante la temporada de lluvias (agosto-diciembre 2016) se colocaron un mes 


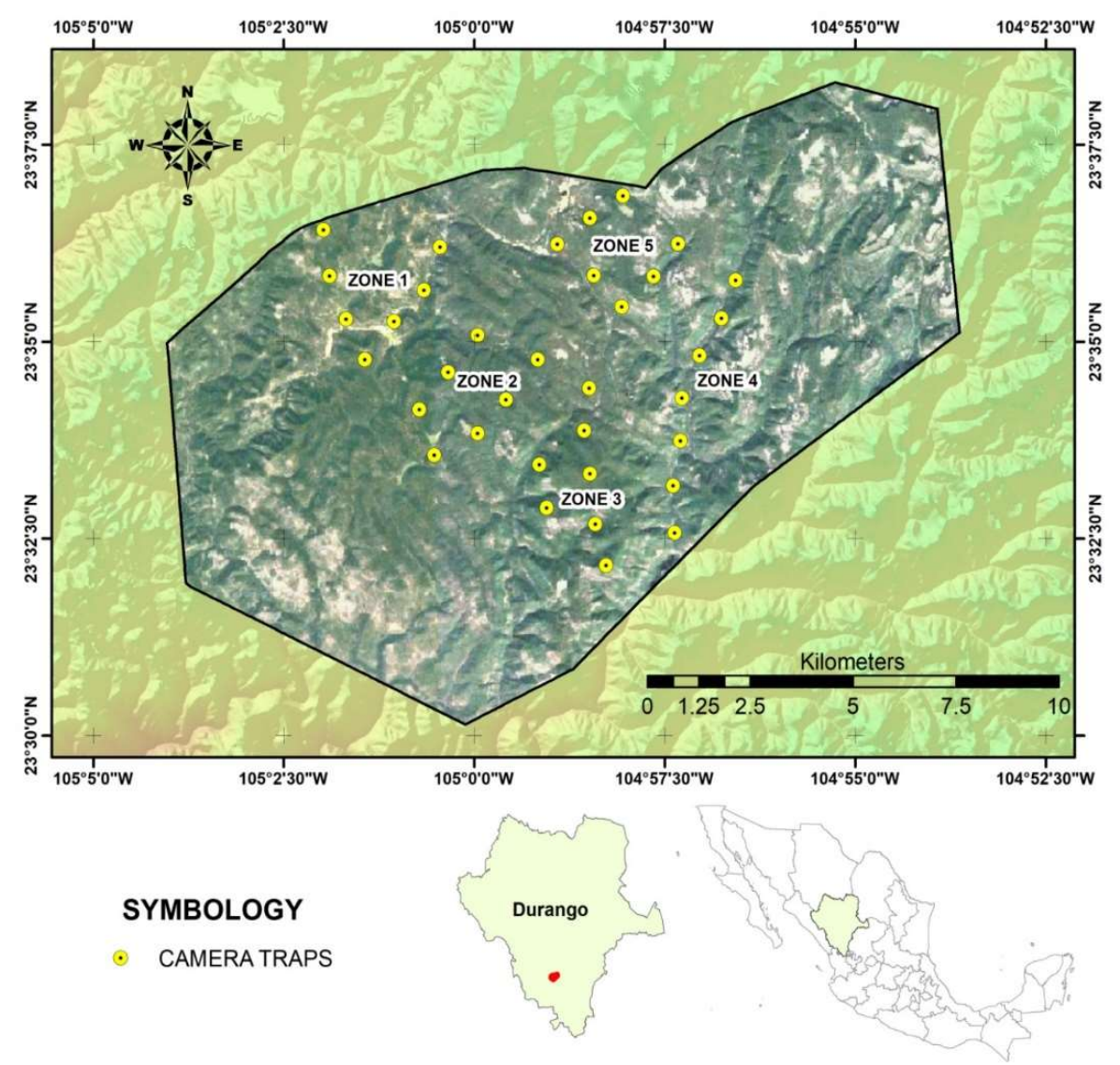

Figure 1. Location of the study zone in the Sierra del Nayar area, Durango, Mexico.

Figura 1. Localización de las zonas de estudio en el predio Sierra del Nayar, Durango, México.

(August-December 2016) they were placed in each zone for one month, the same was done during the dry season (January-May 2017). In this way, there was one month of sampling in each zone for each season, rainy and dry season.

Camera traps (Leafriver iR-7, Stealth Cam SC36NGK2, Stealth Cam STC-P18, and Wildgame T7i) were placed near water bodies, runoff, and trails that could be crossed by wildlife. The devices were placed at an average distance of $1.3 \mathrm{~km}$ between them in each zone.

\section{Abundance and activity patterns}

Photos obtained from the camera traps were inspected to identify individuals at the species level, en cada zona, lo mismo se hizo durante la temporada de secas (enero-mayo 2017). De esta forma, se tuvo un mes de muestreo de cada zona para cada temporada, lluvias y secas.

Las cámaras trampa (marcas Leafriver iR-7, Stealth Cam SC36NGK2, Stealth Cam STC-P18 y Wildgame T7i), se colocaron cerca de cuerpos de agua, escurrimientos y de veredas que pudieran ser paso de fauna. Los dispositivos se establecieron a una distancia promedio de $1.3 \mathrm{~km}$ entre ellas en cada zona.

\section{Abundancia y patrones de actividad}

Se inspeccionaron las fotos obtenidas de las cámaras trampa para identificar los individuos a nivel de especie, en algunos casos con el empleo de literatura 
sometimes using specialized literature (ArandaSanchez, 2012; Alvarez-Castañeda et al., 2017).

The SpecialRenamer, DataOrganize, and DataAnalyze commands of the ReNamer version 4.2 program (SWCCF, 2016) were used to estimate of relative abundance index (RAI) and to describe the patterns of activities by species.

From the information obtained from the photos, the RAI by species was calculated (Liu et al., 2013) with the following equation:

\section{RAI = C / SE x 1000 trap-days}

Where: $\mathrm{C}=$ Captures or events photographed, $\mathrm{SE}=$ Sampling effort (number of camera traps * days of monitoring) seasonal or total. 1000 trap-days (standard unit).

The following cases were considered as independent photographic records: consecutive photographs of different individuals and non-consecutive photographs of the same species (Lira-Torres \& Briones-Salas, 2012; MonroyVilchis et al., 2011).

The activity patterns of species with more than 11 independent photographic records were described (MonroyVilchis et al., 2011). To plot the activity of each species with the Kernel density, the hours of the photos were converted to radians, and the Overlap package was used in the program R Studio 3.4.2 (R Core Team, 2017).

\section{Overlap index}

Based on the number of photos obtained, the overlap index $(\Delta 4)$ of the species that potentially have a predator-prey interaction or competition between predators was determined, and it was verified that such interaction was documented in the literature. The values of $\Delta$ are in the range of 0 (no overlap) to 1 (total overlap) (Ridout \& Linkie, 2009). From each overlap index, its minimum and the maximum value were estimated with a $95 \%$ confidence interval (1,000 bootstrap repetitions).

\section{Statistical Analysis}

In order to make a temporal comparison of the RAls, all the data from the camera traps of each species that were obtained in the rainy and dry seasons and during the study period were merged. Each of especializada (Aranda-Sánchez, 2012; Álvarez-Castañeda et al., 2017).

Para estimar el índice de abundancia relativa (RAl) y describir los patrones de actividades por especies, se emplearon los comandos SpecialRenamer, DataOrganize y DataAnalyze del programa ReNamer versión 4.2 (SWCCF, 2016).

Con la información obtenida de las fotos se calculó el RAI por especie (Liu et al., 2013) con la siguiente fórmula:

\section{RAI = C / SE x 1000 trap-days}

Donde: $\mathrm{C}=$ Capturas o eventos fotografiados, $\mathrm{SE}=$ Esfuerzo de muestreo (número de cámaras trampa * días de monitoreo) estacional o total. 1000 días-trampa (unidad estándar).

Se consideraron como registros fotográficos independientes los siguientes casos: fotografías consecutivas de diferentes individuos y fotografías no consecutivas de la misma especie (Lira-Torres \& Briones-Salas, 2012; Monroy-Vilchis et al., 2011).

Se describieron los patrones de actividad de las especies con más de 11 registros fotográficos independientes (Monroy-Vilchis et al., 2011). Para graficar la actividad de cada especie con la densidad de Kernel, las horas de las fotos se convirtieron a radianes y se utilizó el paquete Overlap en el programa R Studio 3.4.2 (R Core Team, 2017).

\section{Índice de solapamiento}

Con base en el número de fotos obtenidas, se determinó el índice de solapamiento $(\Delta 4)$ de las especies que potencialmente tienen una interacción depredadorpresa o de competencia entre depredadores, se verificó que dicha interacción estuviera documentada en la literatura. Los valores de $\Delta$ están en un rango de 0 ( $\sin$ solapamiento) a 1 (solapamiento total) (Ridout \& Linkie, 2009). De cada índice de solapamiento se estimó su valor mínimo y máximo con un intervalo de confianza del $95 \%$ (1,000 repeticiones de bootstrap).

\section{Análisis estadístico}

Para realizar un comparación temporal de los RAls, se fusionaron todos los datos de las cámaras trampa de cada especie que se obtuvieron en las temporadas de lluvias, secas y durante el periodo de estudio. Se 
the three data sets was inspected for normality using the Shapiro-Wilk test (Zar, 2010). Then, the KruskalWallis test $(p=0.05)$ and Mann-Whitney $U$ test $(p=$ 0.05 ) were used with Bonferroni correction, the latter to make multiple comparisons between the means of the RAl between species by seasons. Seasonal species RAls were grouped based on the paired test matrix of the Mann-Whitney $U$ test results and the box and whiskers plots.

To determine if there were significant differences between the RAls of each species between the wet and dry seasons, a Student t-test analysis or a KruskalWallis test was applied, depending on whether or not the data were normal.

ARayleigh (Z) or Rao (U) uniformity test was performed on the activity data of each species. To determine if there were significant differences between species activity patterns, the non-parametric Watson-Wheeler test was used with the Circular package. The probability value is estimated by assuming that the test statistic follows a Chi-square distribution, the test statistic $\mathrm{W}$ was compared with the probability value $(\alpha=0.05$, Zar, 2010). The statistical analyses were performed with the program R Studio (R Core Team, 2018, R Studio ver. 1.1.463).

\section{Results and Discussion}

The sampling effort was 303 trap days, of which 152 were from the rainy season and 151 from the dry season. Fourteen species were recorded, 13 of the Mammalia class (belonging to five orders and nine families), the best-represented order was carnivorous with six species (Table 1). One species of bird was detected, Meleagris gallopavo. Among the species are those that are difficult to observe, such as Lynx rufus, Puma concolor, $U$. cinereoargenteus, Spilogale gracilis and Bassariscus astutus. The number of species detected with this study is like that reported in other areas of the SMO where camera traps were used (MedinaTorres, 2015). Two (15.4\%) of the recorded species are in some category of risk according to NOM059-SEMARNAT-2010 (SEMARNAT, 2019), while international standards list all species in the category of least-concern (IUCN, 2019). inspeccionó la normalidad de cada uno de los tres conjuntos de datos con la prueba de Shapiro-Wilk (Zar, 2010). Posteriormente se emplearon las pruebas de Kruskal-Wallis $(p=0.05)$ y U de Mann-Whitney $(p=0.05)$ con la corrección de Bonferroni, ésta última para realizar una comparación múltiple entre las medias de los RAI entre especies por temporadas. Se formaron agrupaciones de los RAls de las especies por temporadas, con base a la matriz de pruebas pareadas de los resultados de la prueba de $U$ de Mann-Whitney y los gráficos de cajas y bigotes.

Para determinar si había diferencias significativas entre los RAls de cada especie entre las temporadas de lluvias y secas, se aplicó un análisis de $t$ de Student o una prueba de Kruskal-Wallis, según si los datos presentaron o no normalidad.

Se realizó una prueba de uniformidad de Rayleigh (Z) o Rao (U) de los datos de actividad de cada especie. Para determinar si existían diferencias significativas entre los patrones de actividad de las especies, se utilizó la prueba no paramétrica de WatsonWheeler con el paquete Circular. El valor de probabilidad se estima suponiendo que la estadística de prueba sigue una distribución de Chi-cuadrado, el estadístico de prueba $W$ se comparó con el valor de probabilidad ( $\alpha=0.05, Z a r, 2010)$. Los análisis estadísticos se realizaron con el programa $R$ Studio $(R$ Core Team, 2018, R Studio ver. 1.1.463).

\section{Resultados y Discusión}

El esfuerzo de muestreo fue de 303 días-trampa, de los cuales 152 fueron de la temporada de lluvias y 151 de la temporada de estiaje. Se registraron 14 especies, 13 de la clase Mammalia (pertenecientes a cinco órdenes y nueve familias), el orden mejor representado fue carnívora con seis especies (Tabla 1). Se detectó una especie de ave, Meleagris gallopavo. Entre las especies se encuentran aquellas que son de difícil observación, como por ejemplo Lynx rufus, Puma concolor, U. cinereoargenteus, Spilogale gracilis y Bassariscus astutus. El número de especies detectadas con este estudio es similar a lo reportado en otras áreas de la SMO en las que se usaron cámaras trampa (Medina-Torres, 2015). Dos (15.4\%) de las especies registradas se encuentran en alguna categoría de riesgo de acuerdo a la NOM-059-SEMARNAT-2010 (SEMARNAT, 2019), mientras que las normas internacionales enlistan a todas las especies en la categoría de preocupación menor (IUCN, 2019). 
Table 1.

Recorded species by photo-trapping in the Sierra del Nayar area, Durango, Mexico ( $A=$ Threatened, $\mathrm{Pr}=$ Subjected to special protection).

Tabla 1.

Especies registradas por fototrampeo en el predio Sierra del Nayar, Durango, México ( $A$ = Amenazada, $\operatorname{Pr}=$ Sujeta a protección especial).

\begin{tabular}{|c|c|c|c|}
\hline Family & Scientific name & NOM-059-SEMARNAT-2010 & Number of records \\
\hline Phasianidae & Meleagris gallopavo & & 116 \\
\hline Didelphidae & Didelphis virginiana & & 1 \\
\hline Canidae & Canis latrans & & 55 \\
\hline Canidae & Urocyon cinereoargenteus & & 21 \\
\hline Felidae & Lynx rufus & & 6 \\
\hline Felidae & Puma concolor & & 2 \\
\hline Mephitidae & Spilogale gracilis & & 1 \\
\hline Procyonidae & Bassariscus astutus & A & 1 \\
\hline Cervidae & Odocoileus virginianus & & 142 \\
\hline Tayassuidae & Pecari tajacu & & 44 \\
\hline Sciuridae & Sciurus aberti & $\operatorname{Pr}$ & 99 \\
\hline Sciuridae & Sciurus nayaritensis & & 1 \\
\hline Sciuridae & Neotamias durangae & & 1 \\
\hline Leporidae & Sylvilagus floridanus & & 33 \\
\hline
\end{tabular}

The same species richness was presented in the rainy and dry seasons, unlike other studies conducted in the same ecosystem (Medina-Torres et al., 2015). According to Student and Kruskal-Wallis' t-test statistics $(\alpha=0.05)$, there are no significant intraspecific differences in RAI between the rain and dry seasons for any species (Figure 2). Habitat requirements appear to have remained relatively constant during the study period, which may be due in part to the high rainfall that occurred during the summer and winter of 2016. Precipitation values for the 2017 dry season are relatively higher compared to other years (SMN, 2019). Food may have been abundant during the study period as a cause of precipitation during part of the study period (Rautenstrauch \& Krausman, 1989). For example, in a study of $M$. gallopavo, the observation of large flocks was related to the high abundance of acorns in a forest area in Durango (Garza \& Servin, 1993).

According to the Kruskal-Wallis test there are significant interspecific differences in RAl during the study
Se presentó la misma riqueza de especies en las temporadas de lluvias y secas, a diferencia de otros estudios realizados en el mismo ecosistema (Medina-Torres et al., 2015). De acuerdo a las pruebas estadísticas de t de Student y KruskalWallis $(\alpha=0.05)$, no existen diferencias significativas intraespecíficas de los RAI entre las temporadas de lluvias y secas de ninguna especie (Figura 2). Los requerimientos de hábitat parecen haberse mantenido relativamente constantes durante el periodo de estudio, lo que puede deberse en parte a las altas precipitaciones que se presentaron durante el verano e invierno de 2016. Los valores de precipitación de la temporada de secas de 2017 son relativamente altos en comparación con otros años (SMN, 2019). El alimento pudo haber sido abundante durante el periodo de estudio como causa de las precipitaciones durante parte del periodo de estudio (Rautenstrauch \& Krausman, 1989). Por ejemplo, en un estudio de $M$. gallopavo, se relacionó la observación de grandes bandadas con la alta abundancia de bellotas en un área de bosque en Durango (Garza \& Servín, 1993).

Según la prueba de Kruskal-Wallis existen diferencias significativas interespecíficas de los RAl durante el periodo 

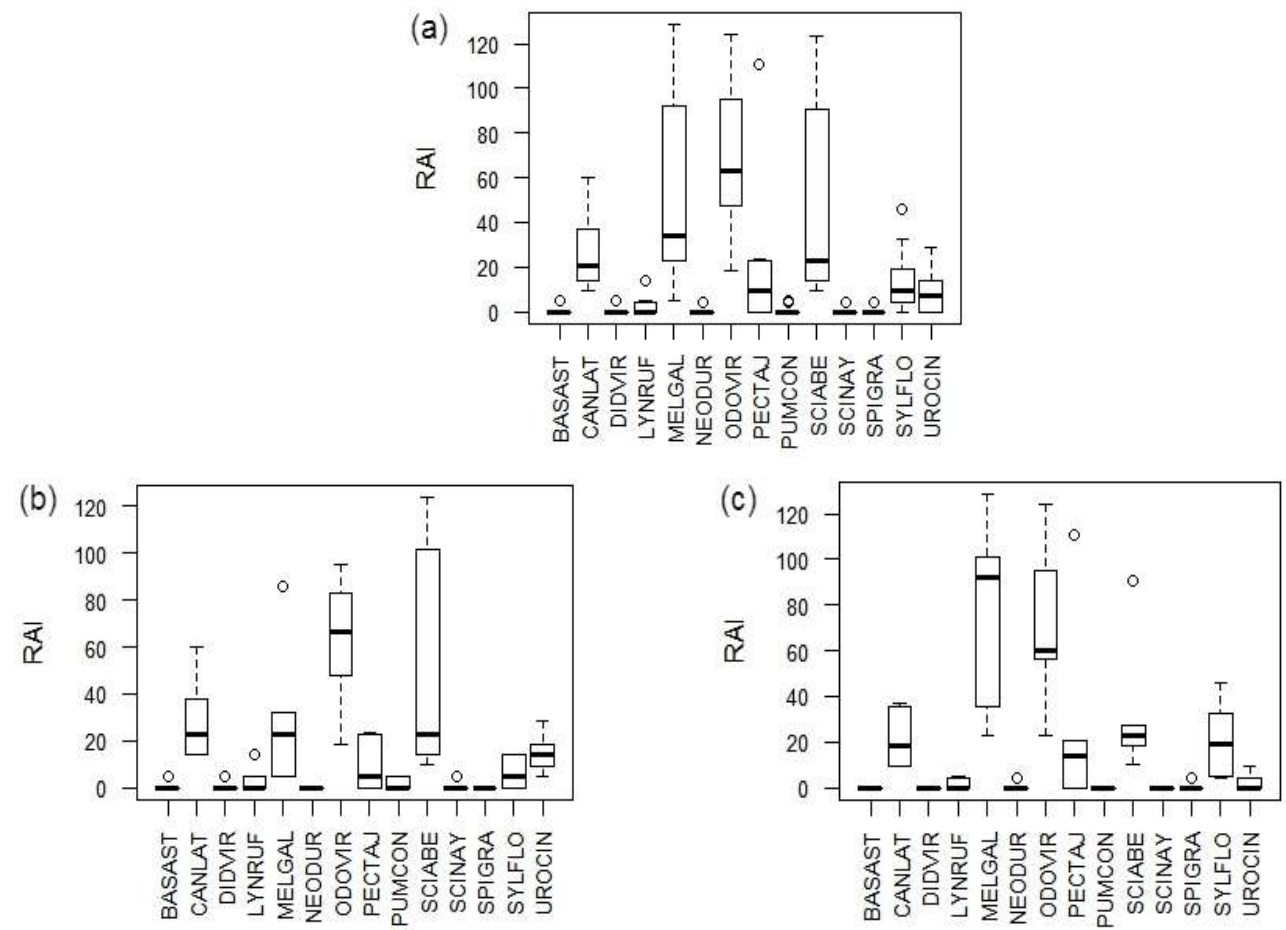

Figura 2. Comparación de los promedios de los indices de abundancia relativa (RAl) de las especies (código de seis letras de los nombres científicos) durante los periodos de: a) estudio, b) lluvias y c) secas en diagramas de cajas (rangos intercuartílicos) y bigotes (valores máximos y mínimos).

Figure 2. Comparison of the averages of relative abundance index (RAI) of the species (six-letter code of the scientific names) during the periods of: a) study, b) rainfall season and c) dry season in box (interquartile ranges) and whiskers (maximum and minimum values) diagrams.

period $(\mathrm{H}=99.8, p<0.05)$, the rainy season $(\mathrm{H}=50.4, p<$ $0.05)$ and the dry season $(H=55.3, p<0.05)$.

During the rainy and dry season, as well as during the study period, the same pattern in RAl levels was presented for the species: Odocoileus virginianus, M. gallopavo, Sciurus aberti and $C$. latrans with the highest RAI; Pecari tajacu, Sylvilagus floridanus, $U$. cinereoargenteus and $L$. rufus at a medium level; and $P$. concolor, B. astutus, D. virginiana, N. durangae, $S$. nayaritensis and $S$. gracilis with the lowest RAl levels. Prey species such as $O$. virginianus and $M$. gallopavo generally have higher RAls, which may show that the mammal community is in balance. This type of dynamic, in which species that are abundant in the rainy season are also abundant in the dry season, has also been observed in other areas of the SMO (Medina-Torres et al., 2015). The patterns in the RAl levels of some species are different de estudio $(\mathrm{H}=99.8, p<0.05)$, la temporada de lluvias $(\mathrm{H}=$ $50.4, p<0.05)$ y la temporada de secas $(H=55.3, p<0.05)$.

Durante la temporada de lluvias y secas, así como en el periodo de estudio, se presentó el mismo patrón en los niveles de RAI para las especies: Odocoileus virginianus, $M$. gallopavo, Sciurus aberti y $C$. latrans con los RAI más altos; Pecari tajacu, Sylvilagus floridanus, U. cinereoargenteus y $L$. rufus en un nivel medio; y $P$. concolor, B. astutus, $D$. virginiana, $N$. durangae, $S$. nayaritensis y $S$. gracilis con los niveles más bajos. Las especies que funcionan como presas como $O$. virginianus y $M$. gallopavo presentan en general RAls más altos, lo que puede indicar que la comunidad de mamíferos está en equilibrio. Este tipo de dinámica, en las que las especies que son abundantes en la temporada de lluvia, también lo son en la de secas, también ha sido observado en otras áreas de la SMO (MedinaTorres et al., 2015). Los patrones en los niveles de los RAI 
from those recorded in other research (Lira-Torres \& Briones-Salas, 2012; Lorenzana-Piña et al., 2004). It can be expected that the RAI of each species will change spatially in the SMO region, because although it is considered a single ecosystem immersed in a mountainous complex, it presents high environmental heterogeneity, as well as areas with different degrees of disturbance that influence the abundance of species (González-Elizondo et al., 2012).

O. virginuanus is one of the most abundant species in the area, which is consistent with other studies conducted in this ecosystem (Medina-Torres et al., 2015). The results obtained for $C$. latrans are similar to others obtained in the center and north of the country (Monroy-Vilchis et al., 2010; Elizalde-Arellano, 2014). Its high abundance may be related to the extirpation of the Mexican wolf (C. lupus baileyi) as one of its competitors in the wild, and that it is a species with a high range of adaptability (Hody \& Kays, 2018).

According to studies (Valdez-Alarcón \& Téllez-Girón, 2005), S. aberti is considered a rare species in its range, in contrast to the present study. According to other research (García-Mendoza \& López-González, 2013), S. nayaritensis is a common species in forested areas of the municipality of Canatlán. In SN S. aberti it was found to have a higher RAI than $S$. nayaritensis. This may be due to the difference in the pressure of competition between these two species, or to factors that are linked to their detection by photo-trapping, since although both are arboreal, the time of activity they spend on the ground may be different (Ramos-Lara \& Koprowski, 2014).

The low RAls SN estimates for $P$. concolor can be related to their wide home ranges, which may reduce the possibility of their being recorded through photo-trapping (Laundre \& Loxterman, 2007). Other detected species that presented lower RAls, refer to those that are generally in low densities in their distribution area and are cryptic (e.g. S. gracilis, Verts et al., 2001), are more of an affinity to the region of the ravines (e.g. N. narica, GarcíaMendoza \& López-González, 2013; Valenzuela-Galvan, 2005) or to the region of the valleys in Durango (e.g. B. astutus, Nava-Vargas, 2005). For N. durangae ÁlvarezCastañeda et al. (2016), they show that it may be abundant in their range, but in the $\mathrm{SMO}$, it is possible that their populations are high only in some localities. de algunas especies son diferentes a los registrados en otras investigaciones (Lira-Torres \& Briones-Salas, 2012; Lorenzana-Piña et al., 2004). Se puede esperar que los RAI de cada especie cambien espacialmente en la región de la SMO, pues, aunque se considera como un solo ecosistema inmerso en un complejo montañoso, presenta una alta heterogeneidad ambiental, además de áreas con diferente grado de disturbio que influyen en la abundancia de especies (González-Elizondo et al., 2012)

O. virginuanus es una de las especies más abundantes en el área, lo que concuerda con otros estudios realizados en este ecosistema (Medina-Torres et al., 2015). Los resultados obtenidos para $C$. latrans son similares a otros obtenidos en el centro y norte de país (Monroy-Vilchis et al., 2010; Elizalde-Arellano, 2014). Su abundancia alta puede estar relacionada con la extirpación del lobo mexicano ( $C$. lupus baileyi) como uno de sus competidores en el medio de vida silvestre, y a que es una especie con un alto rango de adaptabilidad (Hody \& Kays, 2018).

Según estudios (Valdez-Alarcón \& Téllez-Girón, 2005), $S$. aberti es considerada una especie rara en su rango de distribución, en contraste con el presente estudio. De acuerdo a otra investigación (García-Mendoza \& LópezGonzález, 2013), S. nayaritensis es una especie común en áreas boscosas del municipio de Canatlán. En SN S. aberti se encontró con RAI más alto que $S$. nayaritensis. Esto puede ser por la diferencia en la presión de competencia entre estas dos especies, o por factores que están ligados a su detección por fototrampeo, ya que aunque ambas son arborícolas el tiempo de actividad que pasan en el suelo puede ser diferente (Ramos-Lara \& Koprowski, 2014).

Los RAls bajos estimados en SN para $P$. concolor se pueden relacionar a sus rangos hogareños amplios, lo que puede reducir la posibilidad de que sean registradas a través de fototrampeo (Laundre \& Loxterman, 2007). Otras de las especies detectadas que presentaron los RAls más bajos, se refieren a aquellas que en general están en bajas densidades en su área de distribución y son crípticas (p.e. S. gracilis, Verts et al., 2001), son más de afinidad a la región de las quebradas (p.e. N. narica, García-Mendoza \& López-González 2013; Valenzuela-Galvan, 2005) o a la región de los valles en Durango (p.e. B. astutus, NavaVargas, 2005). Para N. durangae Álvarez-Castañeda et al. (2016), señalan que puede ser abundante en su rango de distribución, pero en la SMO es posible que sus poblaciones sean altas solo en algunas localidades. 
Of the five species from which the activity pattern was obtained, all presented a uniform distribution of data, according to Rayleigh and Rho tests $(p=0.01)$. $M$. gallopavo $(Z=0.035)$ presented a diurnal activity, with a peak of activity between $13: 00$ and 15:00 $\mathrm{h}$; C. latrans $(Z=0.032)$ with cathemeral activity; $U$. cinereoargenteus $(Z=0.075)$ recorded bimodal activity (one peak between 23:00 and 1:00 h and another between $4: 00$ and 8:00 h); $S$. aberti $(U=206.85)$ with a peak between 9:00 and 12:00 h; and S. floridanus (U = 94.87 ) with a peak of activity between $24: 00$ and 1:00 h (Figure 3).

The results on activity patterns for C. latrans, $U$. cinereoargenteus, and $S$. floridanus are consistent
De las cinco especies de las que se obtuvo el patrón de actividad, todas presentaron una distribución uniforme de los datos, de acuerdo a las pruebas de Rayleigh y Rho ( $p$ $=0.01)$. $M$. gallopavo $(Z=0.035)$ presentó una actividad diurna, con un pico de actividad entre las 13:00 y 15:00 h; C. latrans $(Z=0.032)$ con actividad catameral; $U$. cinereoargenteus $(Z=0.075)$ registró actividad bimodal (un pico entre $23: 00$ y $1: 00 \mathrm{~h}$ y otro entre $4: 00$ y $8: 00 \mathrm{~h}$ ); $S$. aberti $(U=206.85)$ con un pico entre 9:00 y 12:00 h; y $S$. floridanus $(\mathrm{U}=94.87)$ con un pico de actividad entre las 24:00 y 1:00 h (Figura 3).

Los resultados en los patrones de actividad para C. latrans, $U$. cinereoargenteus y $S$. floridanus concuerdan con lo reportado en la literatura (Bekoff \& Wells, 1982; Arias-Del
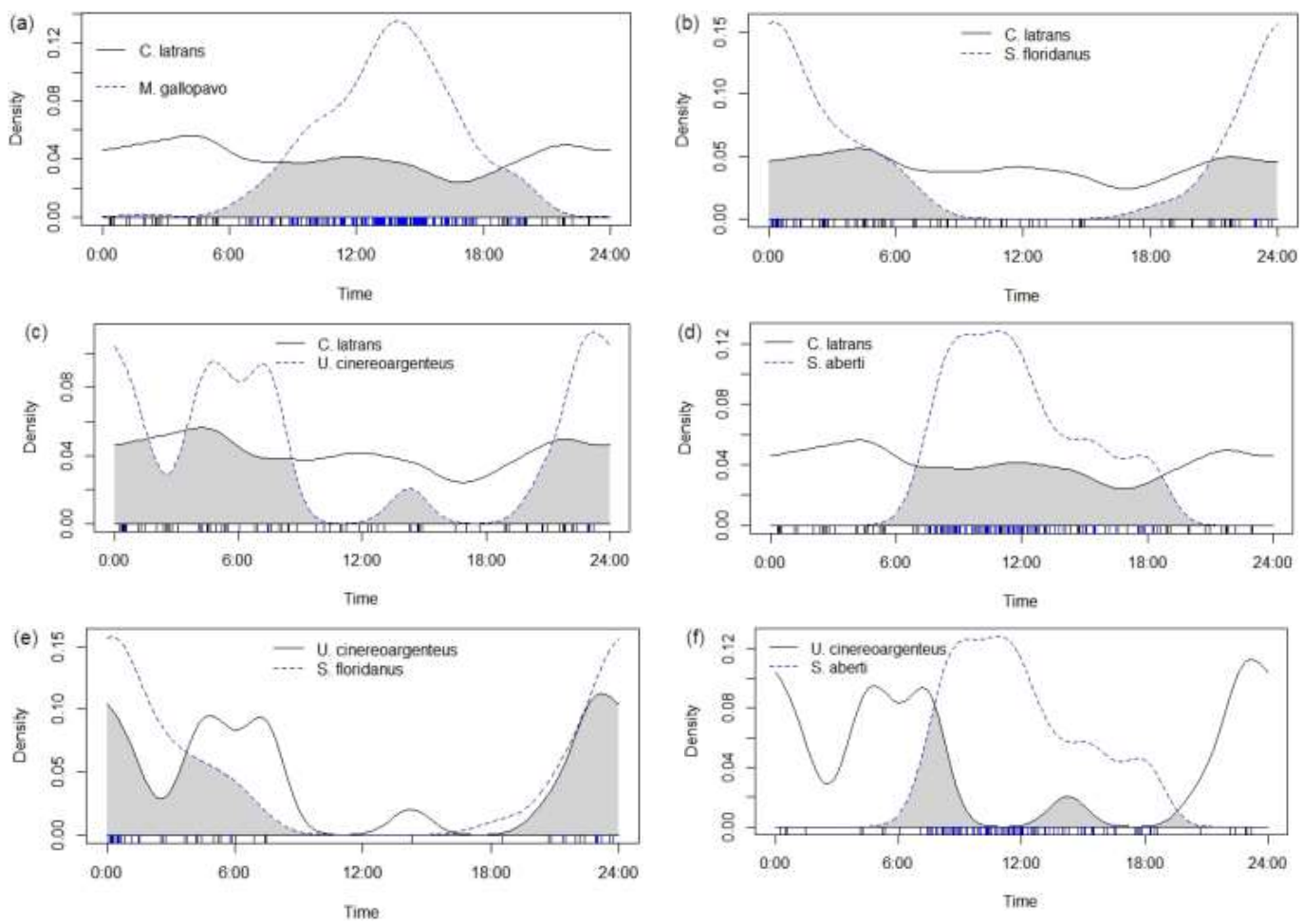

Figure 3. Overlapping activity patterns of: a) Canis latrans-Meleagris gallopavo, b) Canis latrans-Sylvilagus floridanus, c) Canis latrans-Urocyon cinereoargenteus, d) Canis latrans-Sciurus aberti, e) Urocyon cinereoargenteusSylvilagus floridanus and f) Urocyon cinereoargenteus-Sciurus aberti.

Figura 3. Solapamiento de los patrones de actividad de: a) Canis latrans-Meleagris gallopavo, b) Canis latrans-Sylvilagus floridanus, c) Canis latrans-Urocyon cinereoargenteus, d) Canis latrans-Sciurus aberti, e) Urocyon cinereoargenteus-Sylvilagus floridanus y f) Urocyon cinereoargenteus-Sciurus aberti. 
with those reported in the literature (Bekoff \& Wells 1982; Arias-Del Razo, 2011; González-Pérez, 1992; Monroy-Vilchis et al., 2011). The unimodal activity pattern of $S$. aberti is like that of other species of sciurids (Wassmer \& Refinetti, 2016). The number of photos, although low, that were obtained from $D$. virginiana, S. gracilis and $B$. astutus, evidence nocturnal or twilight activity patterns, as found in other studies (Monroy-Vilchis et al., 2011).

We reviewed in the literature the feasibility of 11 interactions for analysis, of which five were discarded: predation by $C$. latrans and $U$. cinereoargenteus on $O$. virginianus and P. tajacu, and predation by U. cinereoargenteus on M. gallopavo, since these species are not part of the diet of these canids, or predation on specific age groups (Fritzel \& Haroldson, 1982; Patterson \& Messier, 2003). From five species, the overlap index was estimated for six interactions: C. latrans-M. gallopavo, C. latrans-S. floridanus, C. latrans-U. cinereoargenteus, C. latrans-S. aberti, $U$. cinereoargenteus-S. floridanus and $U$. cinereoargenteus-S. aberti with overlap indices of 0.19 to 0.70 . C. latrans-U. cinereoargenteus and $U$. cinereoargenteus-S. floridanus interactions did not show significant differences in their activity patterns. In other interactions, the differences were highly significant (Table 2).

The interaction of $U$. cinereoargenteus-S. floridanus had the highest rate of overlap, with no significant differences
Razo, 2011; González-Pérez, 1992; Monroy-Vilchis et al., 2011). El patrón de actividad unimodal de $S$. aberti es similar al de otras especies de esciúridos (Wassmer \& Refinetti, 2016). El número de fotos, aunque bajo, que se obtuvieron de $D$. virginiana, S. gracilis y $B$. astutus, evidencian patrones de actividad nocturnos o crepusculares, de acuerdo a lo encontrado en otros estudios (Monroy-Vilchis et al., 2011).

Se revisó en la literatura la factibilidad de 11 interacciones para análisis, de éstas se descartaron cinco: depredación de $C$. latrans y $U$. cinereoargenteus sobre $O$. virginianus y $P$. tajacu, y depredación de $U$. cinereoargenteus sobre $M$. gallopavo, ya que esas especies no son parte de la dieta de esos cánidos, o bien, depredan sobre grupos específicos de edad (Fritzel \& Haroldson, 1982; Patterson \& Messier, 2003). De cinco especies se estimó el índice de solapamiento para seis interacciones: C. latrans-M. gallopavo, C. latrans-S. floridanus, C. latrans-U. cinereoargenteus, $C$. latrans-S. aberti, $U$. cinereoargenteus-S. floridanus y $U$. cinereoargenteus-S. aberti con índices de solapamiento de 0.19 a 0.70 . Las interacciones $C$. latrans- $U$. cinereoargenteus y $U$. cinereoargenteus-S. floridanus no presentaron diferencias significativas en sus patrones de actividad. En las demás interacciones las diferencias fueron altamente significativas (Tabla 2).

La interacción de $U$. cinereoargenteus-S. floridanus tuvo el más alto índice de solapamiento, sin diferencias significativas en sus patrones de actividad, con una convergencia principalmente por los hábitos nocturnos y

Table 2.

Overlap index $(\Delta)$ and Watson - Wheeler statistical test $\mathbf{( W}=$ Watson - Wheeler statistical, $p=$ probability) of the pattern of species activity in the Sierra del Nayar area.

Tabla 2.

Índice de solapamiento $(\Delta)$ y prueba estadística de Watson - Wheeler (W = estadístico de WatsonWheeler, $\mathbf{p}=$ probabilidad) del patrón de actividad de especies en el predio Sierra del Nayar.

\begin{tabular}{lccccc}
\hline \multicolumn{1}{c}{ Interaction } & $\Delta$ & \multicolumn{2}{c}{ Confidence Interval (95 \%) } & \multirow{2}{*}{ w } & p \\
\cline { 3 - 5 } & & Minimum & Maximum & & \\
\hline C. latrans-M. gallopavo & 0.47 & 0.37 & 0.58 & 57.3 & 0.001 \\
C. latrans-S. floridanus & 0.59 & 0.44 & 0.73 & 21.6 & 0.001 \\
C. latrans-U. cinereoargenteus & 0.62 & 0.47 & 0.77 & 5.6 & 0.08 \\
C. latrans-S. aberti & 0.45 & 0.34 & 0.55 & 42.5 & 0.001 \\
U. cinereoargenteus-S. floridanus & 0.70 & 0.52 & 0.88 & 4.9 & 0.06 \\
U. cinereoargenteus-S. aberti & 0.19 & 0.08 & 0.32 & 40.3 & 0.001 \\
\hline
\end{tabular}


in its activity patterns, with convergence mainly due to the nocturnal and crepuscular habits of $S$. floridanus. Research in Mexico and the United States reports lagomorphs as an important part of the diet of $U$. cinereoargenteus (Arnaud \& Acevedo, 1990). U. cinereoargenteus vision may be limited under low light conditions, which may affect its predation strategies (Fritzell \& Haroldson, 1982). Supplementary dietary studies would confirm the degree to which rabbits are preyed upon by $U$. cinereoargenteus, as it is a species with a range of dietary adaptability, with changes in its diet depending on the season and availability of food (Guerrero et al., 2002).

C. latrans and $U$. cinereoargenteus appear in sympatry competing for food resources, while $U$. cinereoargenteus can be depredated by $C$. latrans. There may be a high overlap in the food niche of both species and a possible distribution of resources, so that competition may be reduced (González-Pérez, 1992; Guerrero et al., 2002). In the United States, it has been reported that $U$. cinereoargenteus has the potential to distribute in areas of lower C. latrans presence. This and the arboreal behavior of $U$. cinereoargenteus may reduce the risk of coyote predation (González-Pérez, 1992; Fedriani et al., 2000). The low abundance of $U$. cinereoargenteus relative to C. latrans may be explained in part by the dual interaction; further studies may reveal whether this pattern is spatially and temporally constant in SMO.

Other research has also found significant differences on $\Delta$ between predators and various of their prey (AvilaNájera et al., 2016). Some of their arguments to explain this may be applicable for the present research, but other biological factors can be mentioned for the case of $\mathrm{SN}$, such as those explained below.

Although the predation of C. latrans on M. gallopavo has been documented (Spears et al., 2003), and it has been concluded that in areas of the SMO, birds are part of their diet, they may represent a smaller proportion with respect to mammals (Servin \& Huxley, 1991). The frequency of encounters between both species can be relatively high in $\mathrm{SN}$ due to the constant diurnal activity of the coyote, but their attack efficiency can be low (Begon et al., 2006). Significant differences were also found in the interaction between C. latrans-S. floridanus. Lagomorphs may be part of the coyote's diet, but because they are an opportunistic crepusculares de $S$. floridanus. Investigaciones realizadas en México y Estados Unidos reportan a los lagomorfos como parte importante de la dieta de $U$. cinereoargenteus (Arnaud \& Acevedo, 1990). La visión de U. cinereoargenteus puede ser limitada bajo condiciones de poca luz, lo que puede afectar sus estrategias depredatorias (Fritzell \& Haroldson, 1982). Estudios complementarios sobre dieta confirmarían el grado al que los conejos son depredados por $U$. cinereoargenteus, pues es una especie con una amplia adaptabilidad alimenticia, con cambios en su dieta según la estación del año y la disponibilidad de alimento (Guerrero et al., 2002).

C. latrans y $U$. cinereoargenteus se presentan en simpatría compitiendo por recursos alimenticios, a su vez $U$. cinereoargenteus puede ser depredada por C. latrans. Puede existir una alta sobreposición del nicho alimenticio de ambas especies y una posible repartición de recursos, por lo que la competencia se puede reducir (González-Pérez, 1992; Guerrero et al., 2002). En Estados Unidos se ha reportado que $U$. cinereoargenteus tiene la posibilidad de distribuirse en áreas de menor presencia de $C$. latrans. Con lo anterior y la conducta arborícola de $U$. cinereoargenteus posiblemente se reduzca el riesgo de depredación por coyotes (González-Pérez, 1992; Fedriani et al., 2000). La baja abundancia de $U$. cinereoargenteus con relación al C. latrans tal vez se explique en parte por la interacción dual, estudios adicionales pueden revelar si este patrón es constante espacial y temporalmente en la SMO.

Otras investigaciones también han encontrado diferencias significativas en el $\Delta$ entre depredadores y varias de sus presas (Ávila-Nájera et al., 2016). Algunos de sus argumentos para explicarlo pueden ser aplicables para la presente investigación, pero se pueden mencionar otros factores biológicos para el caso de $\mathrm{SN}$, como los que se explican a continuación.

Aunque está documentada la depredación de $C$. latrans sobre M. gallopavo (Spears et al., 2003), y a que se ha concluido que en áreas de la SMO las aves forman parte de su dieta, estas pueden representar una proporción mucho menor con respecto a los mamíferos (Servín \& Huxley, 1991). La frecuencia de encuentro entre ambas especies puede ser relativamente alta en SN por la actividad diurna constante del coyote, pero su eficiencia de ataque puede ser baja (Begon et al., 2006). También se presentaron diferencias significativas en la interacción C. latrans-S. floridanus. Los lagomorfos pueden ser parte de la dieta del coyote, pero al ser una especie oportunista 
species, they may be feeding on other resources such as rodents or fruits in SN (Servin \& Huxley, 1991).

The activity patterns of $U$. cinereoargenteus (twilight and nocturnal) and $S$. aberti (diurnal), make the $\Delta$ of this interaction the lowest of all. In the case of $S$. aberti, their ability to climb trees may make it difficult for $C$. latrans to hunt them (Ramos-Lara \& Koprowski 2015).

\section{Conclusions}

The species with the highest RAl in the study area were: O. virginianus, M. gallopavo, S. aberti and $C$. latrans. The interactions $U$. cinereoargenteus-S. floridanus and C. latrans-U. cinereoargenteus had the highest overlap index and no significant differences in their activity patterns. The activity patterns of the species studied are similar to those reported in the North American literature. The findings allow us to better understand the interactions between some mammal species at a local scale. Studies of spatial aspects that can also be obtained from photo-trapping, as well as other complementary ecological research in other locations of the SMO, would allow a better understanding of more specific aspects of these interactions in this ecosystem.

\section{Acknowledgments}

To the owners of the Sierra del Nayar property, Municipality of Durango, Durango, for the support given to carry out the activities in the field, especially the directors of the property, Mr. Rodrigo Ortíz Robles and Mr. César Rojas Rojas for allowing us to carry out the work on their land, to the Consultant Forestal Durango S. de R.L. de C.V. for help in the fieldwork. puede estar alimentándose de otros recursos como roedores o frutos en SN (Servín \& Huxley, 1991).

Los patrones de actividad de $U$. cinereoargenteus (crepusculares y nocturnos) y S. aberti (diurnos), hacen que el $\Delta$ de esta interacción sea el más bajo de todas. En el caso de S. aberti, su habilidad para trepar árboles puede dificultar que sea cazada por C. latrans (Ramos-Lara \& Koprowski, 2015).

\section{Conclusiones}

Las especies con los RAI más altos en el área de estudio fueron: $O$. virginianus, $M$. gallopavo, $S$. aberti y $C$. latrans. Las interacciones $U$. cinereoargenteus-S. floridanus y $C$. latrans- $U$. cinereoargenteus tuvieron el más alto índice de solapamiento y no presentaron diferencias significativas en sus patrones de actividad. Los patrones de actividad de las especies estudiadas son similares a lo reportado por la literatura en Norteamérica. Los hallazgos encontrados permiten comprender mejor las interacciones entre algunas especies de mamíferos a una escala local. Estudios de aspectos espaciales que puede obtenerse también del fototrampeo, así como otras investigaciones ecológicas complementarias en otras localidades de la SMO, permitirían tener un mejor entendimiento de aspectos más específicos de dichas interacciones en este ecosistema.

\section{Agradecimientos}

A los condueños del predio Sierra del Nayar, Municipio de Durango, Durango, por el apoyo brindado para realizar las actividades en campo, en especial los directivos del predio, Sr. Rodrigo Ortíz Robles y Sr. César Rojas Rojas por permitirnos realizar el trabajo en sus terrenos, al Despacho Consultora Forestal Durango S. de R.L. de C.V. por la ayuda en el trabajo de campo.

\section{References}

Álvarez-Castañeda, S. T., Álvarez, T. and González-Ruíz, N. (2017). Guía para identificar los mamíferos de México (Keys for identifying mexican mammals), First edition. Baja California Sur, Mexico. Centro de Investigaciones Biológicas del Noroeste, S.C., Escuela Nacional de Ciencias Biológicas, Universidad Autónoma Metropolitana.

Álvarez-Castañeda, S. T., Lacher, T. and E. Vázquez. (2016). Neotamias durangae. The IUCN Red List of Threatened Species. https://www.iucnredlist.org/. [Last Checked: October 10 $0^{\text {th }} 2019$ ].

Aragón, E. E., Garza, A. and Cervantes, F. A. (2009). Estructura y organización de los ensambles de roedores de un bosque de la Sierra Madre Occidental, Durango, México. Revista Chilena de Historia Natural, 82(4): 523-542. http:// dx.doi.org/10.4067/S0716-078X2009000400007 
Aranda-Sánchez, J. M. (2012). Manual para el rastreo de mamíferos silvestres de México. First edition Comisión Nacional para el Conocimiento y Uso de la Biodiversidad (CONABIO). http://bioteca.biodiversidad.gob.mx/janium/ Documentos/6800.pdf

Arias-Del Razo I., Hernández, L., Laundré, J. W. and O. Myers. (2011). Do predator and prey foraging activity patterns match? A study of coyotes (Canis latrans) and lagomorphs (Lepus californicus and Sylvilagus audubonii). Journal of Arid Environments, 75(2): 112-118. https://doi.org/10.1016/j.jaridenv.2010.09.008

Arnaud, G. \& Acevedo, M. (1990). Hábitos alimenticios de la zorra gris Urocyon cinereoargenteus (Carnivora: Canidae) en la región meridional de Baja California, México. Revista de Biología Tropical, 38(2): 497-500. https://revistas. ucr.ac.cr/index.php/rbt/article/view/25676

Arroyo-Rodríguez, V. (2005). Uso de diferentes asociaciones vegetales por lagomorfos en Mapimí, Durango, México. Acta Zoológica Méxicana, 21(3): 151-153. http://www.scielo.org.mx/pdf/azm/v21n3/v21n3a9.pdf

Ávila-Nájera, D. M., Chávez, C., Lazcano-Barreto, M. A., Mendoza, G. D. and Pérez-Elizalde, S. (2016). Overlap in activity patterns between big cats and their main prey in northern Quintana Roo, Mexico. Therya, 7(3): 439-448. 10.12933/therya-16-379 ISSN 2007-3364

Balme, G. A., Hunter, L. T. and Slotow, R. O. B. (2009). Evaluating methods for counting cryptic carnivores. The Journal of wildlife management, 73(3): 433-441. https://doi.org/10.2193/2007-368

Begon, M., Townsend, C. R. and Harper, J. L. (2006). Ecology: from individuals to ecosystems, Fourth edition. Oxford, United Kingdom. Blackwell Publishing.

Bekoff, M. \& Wells, M. C. (1982). Behavioral ecology of coyotes: social organization, rearing patterns, space use, and resource defense. Zeitschrift für Tierpsychologie, 60(4): 281-305. https://doi.org/10.1111/j.1439-0310.1982. tb01087.x

Botello, F., Sánchez-Cordero, V. and Gonzalez, G. (2008). Diversidad de carnívoros en Santa Catarina Ixtepeji, Sierra Madre de Oaxaca, México. In: Avances en el estudio de los mamíferos de México. Lorenzo, C., E. Espinoza, y Ortega, J., ed. 335-354 pp. Mexico, Federal District. https://www.researchgate.net/publication/286331606 Diversidad_de_carnivoros_en_santa_catarina_ixtepeji sierra_madre_de_oaxaca_mexico

Comisión Nacional para el Conocimiento y Uso de la Biodiversidad [CONABIO]. www.biodiversidad.gob.mx. [Last Checked: February $\left.23^{\text {th }} 2017\right]$.

Elizalde-Arellano, C., López-Vidal, J. C., Hernández-García, L., Laundré, J. W., Cervantes-Reza F., Morales-Mejía, F. M., Ramirez-Vargas, M., Dávila-Galaviz, L. F., Gonzáles-Romero, A. and Alonso-Spilsbury, M. (2014). Registro de presencia y actividades de algunos mamíferos en el Desierto Chihuahuense, México. Therya, 5(3): 793-816. https://doi.org/10.12933/therya-14-252

Fedriani, J. M., Fuller, T. K., Sauvajot, R. M. and York, E. C. (2000). Competition and intraguild predation among three sympatric carnivores. Oecologia, 125(2): 258-270. https://doi.org/10.1007/s004420000448

Frey, S., Fisher, J. T., Burton, A. C. and Volpe, J. P. (2017). Investigating animal activity patterns and temporal niche partitioning using camera trap data: challenges and opportunities. Remote Sensing in Ecology and Conservation, 3: 123132. https://doi.org/10.1002/rse2.60

Fritzell, E. K. \& Haroldson, K. J. (1982). Urocyon cinereoargenteus. Mammalian species, 189: 1-8. https://doi. org/10.2307/3503957

García-Mendoza, D. F. \& López-González, C. (2013). A checklist of the mammals (Mammalia) from Durango, western Mexico. Check List, 9(2): 313-322. https://www.biotaxa.org/cl/article/view/9.2.313/11614

Garza, A. \& Servín, J. (1993). Estimación de la población y utilización del hábitat de cócono silvestre (Meleagris gallopavo. Aves: phasianidae) en Durango, México. Ecologia Austral, 3(1): 15-23. http://hdl.handle.net/20.500.12110/ ecologiaaustral_v003_n01_p015

Gittleman, J. L., Funk, S. M., Macdonald, D. W. and Wayne, R. K. (2001). Carnivore conservation, First edition. Cambridge, United Kingdom. Cambridge University Press.

Gómez-Valenzuela, C., Flores-Zamarripa, F. J. and Fernández, J. A. (2017). Nuevos registros para el mapache Procyon lotor (Carnivora: Procyonidae) y el tlalcoyote, Taxidea taxus (Carnivora: Mustelidae) en Chihuahua y Durango, México. Acta Zoológica Mexicana, 33(2): 394-397. http://www.scielo.org.mx/pdf/azm/v33n2/2448-8445azm-33-02-00394.pdf 
González-Elizondo, M. S., González-Elizondo, M., Tena-Flores, J. A., Ruacho-González, L. and López-Enríquez, I. L. (2012). Vegetación de la sierra madre occidental, México: Una síntesis. Acta Botánica Mexicana, 100: 351-403. https:// doi.org/10.21829/abm100.2012.40

González-Pérez, G. E., Sánchez-Bernal, V. M., Îniguez-Dávalos, L. I., Santana, C. E. and Fuller, T. K. (1992). Patrones de actividad del coyote (Canis latrans), la zorra gris (Urocyon cinereoargenteus) y el tlacuache (Didelphis virginiana) en la sierra de Manantlán, Jalisco. Anales del Instituto de Biología. Serie Zoología, 63(2): 293-299. https://www.redalyc.org/pdf/458/45863215.pdf

Grajales-Tam, K. M. \& González-Romero, A. (2014). Determinación de la dieta del coyote (Canis latrans) en la región norte de la reserva de la Biosfera Mapimí, México. Revista Mexicana de Biodiversidad, 85(2): 553-564. https://doi. org/10.7550/rmb.35226

Guerrero, S., Badii, M. H., Zalapa, S. S. and Flores, A. E. (2002). Dieta y nicho de alimentación del coyote, zorra gris, mapache y jaguarundi en un bosque tropical caducifolio de la costa sur del estado de Jalisco, México. Acta Zoológica Mexicana, 86: 119-137. http://www.scielo.org.mx/pdf/azm/n86/n86a7.pdf

Hody, J. W. \& Kays, R. (2018). Mapping the expansion of coyotes (Canis latrans) across North and Central America. ZooKeys, 759:81-97. http//doi.org/10.3897/zookeys.759.15149

Unión Internacional para la Conservación de la Naturaleza [IUCN]. www.iucnredlist.org. [Last Checked: September $20^{\text {th }}$ 2019].

Laundre, J. W. \& Loxterman J. (2007). Impact of edge habitat on summer home range size in female pumas. The American Midland Naturalist, 157(1): 221-230. https://doi.org/10.1674/0003-0031(2007)157[221:IOEHOS]2.0.CO:2

Laurance, W. F., Vasconcelos, H. L. and Lovejoy, T. E. (2000). Forest loss and fragmentation in the Amazon: implications for wildlife conservation. Oryx, 34(1): 39-45. https://doi.org/10.1046/j.1365-3008.2000.00094.x

Lira-Torres, I. \& Briones-Salas, M. (2012). Abundancia relativa y patrones de actividad de los mamíferos de los Chimalapas, Oaxaca, México. Acta Zoológica Mexicana, 28(3): 566-585. http://www.scielo.org.mx/pdf/azm/ $\underline{\mathrm{v} 28 \mathrm{n} 3 / \mathrm{v} 28 \mathrm{n} 3 \mathrm{a} 6 \mathrm{.pdf}}$

Liu, X., Wu, P., Songer, M., Cai, Q., He, X., Zhu, Y. and Shao, X. (2013). Monitoring wildlife abundance and diversity with infra-red camera traps in Guanyinshan Nature Reserve of Shaanxi Province, China. Ecological Indicators, 33, 121-128. https://doi.org/10.1016/i.ecolind.2012.09.022

Lorenzana-Piña, G. P., Castillo-Gamez, R. A. and López-González, C. A. (2004). Distribution, habitat association and activity patterns of medium and large sized mammals of Sonora, México. Natural Areas Journal, 24(4): 354-357. https:// investigadores.unison.mx/en/publications/distribution-habitat-association-and-activity-patterns-of-medium-

Mandujano, S. (2019). Analysis and trends of photo-trapping in Mexico: text mining in R. Therya, 10(1): 25-32. https://doi. org/10.12933/therya-19-666

Martínez-Guerrero, J. H., Nocedal, J., Sierra-Franco, D., Arroyo-Arroyo, S. I. and Pereda-Solís, M. E. (2018). Nueva localidad del gorrión serrano en peligro de extinción (Xenospiza baileyi) en el estado de Durango, México, y recomendaciones para su conservación. Acta Zoológica Mexicana, 34: 1-6. https://doi.org/10.21829/ azm.2018.3412115

Medina-Torres, S. M., Gastélum-Vizcarra, E. L., Lara-Ponce, E. and Piña-Ruiz, H. H. (2015). Inventario participativo de mamíferos silvestres en el ejido San Ignacio, municipio de Morelos, Chihuahua. Acta Zoológica Mexicana, 31(2): 221-233. http://www.scielo.org.mx/pdf/azm/v31n2/v31n2a9.pdf

Monroy-Vilchis, O., Zarco-González, M., Rodríguez-Soto, C., Soria-Díaz, L. and Urios, V. (2011). Fototrampeo de mamíferos en la Sierra Nanchititla, México: abundancia relativa y patrón de actividad. Revista de Biología Tropical, 59(1): 373-383. https://revistas.ucr.ac.cr/index.php/rbt/article/view/3206

Nava-Vargas, V. (2005). Cacomixtle. In: Los Mamíferos Silvestres de México. Ceballos G., y G. Oliva, ed. 408-409 pp. Comisión Nacional para el Conocimiento y Uso de la Biodiversidad, Fondo de Cultura Económica. Mexico, Federal District.

Ojeda, R. A., Stadler, J. and Brandl, R. (2003). Diversity of mammals in the tropical-temperate Neotropics: hotspots on a regional scale. Biodiversity and Conservation, 12(7): 1431-1444. https://doi.org/10.1023/A:1023625125032

Patterson, B. R. \& Messier, F. (2003). Age and condition of deer killed by coyotes in Nova Scotia. Canadian Journal of Zoology, 81(1): 1894-1898. https://doi.org/10.1139/z03-189 
R Core Team. (2018). R: A language and environment for statistical computing. R Foundation for Statistical Computing, Vienna, Austria. https://www.r-project.org/

Ramírez-Muñoz, D., Orona-Espino, A., Estrada-Rodríguez, J. L. and Leyva-Pacheco, S. V. (2012). Inventario de mamíferos en el macizo montañoso denominado sierra El Sarnoso Durango, México. Agrofaz: publicación semestral de investigación científica, 12(1): 73-79. https://dialnet.unirioja.es/servlet/articulo? codigo=5521589

Ramos-Lara, N. \& Koprowski, J. L. (2014). Deforestation and knowledge gaps threaten conservation of less charismatic species: status of the arboreal squirrels of Mexico. Mammalia, 78(4): 417-427. https://www.degruyter.com/view/ journals/mamm/78/4/article-p417.xml

Rautenstrauch, K. R. \& Krausmann, P. R. (1989). Influence of water availability on rainfall and movements of desert mule deer. Journal of Mammalogy, 70(1): 197-201. https://doi.org/10.2307/1381689

Ridout, M. S. \& Linkie, M. (2009). Estimating overlap of daily activity patterns from camera trap data. Journal of Agricultural Biological Environmental Statistics, 14: 322-337. https://doi.org/10.1198/jabes.2009.08038

Schoener, T. W. (1974). Resource partitioning in ecological communities. Science, 185: 27-39. http://doi.org/10.1126/ science.185.4145.27

Secretaría de Medio Ambiente y Recursos Naturales [SEMARNAT]. Norma Oficial Mexicana NOM-059-Ecol-2010. Protección ambiental, especies nativas de México de flora y fauna silvestres, categorías de riesgo y especificaciones para su inclusión, exclusión o cambio. Lista de especies en riesgo. http://biblioteca.semarnat.gob.mx/janium/ Documentos/Ciga/agenda/DOFsr/DO2454.pdf. [Last Checked: August 28 ${ }^{\text {th }}$ 2019].

Servín, J. \& Huxley, C. (1991). La dieta del coyote en un bosque de encino-pino de la Sierra Madre Occidental de Durango, México. Acta Zoológica Mexicana, 44: 1-26. http://azm.ojs.inecol.mx/index.php/azm/article/view/1684

Servín, J., Bejarano, A., Alonso-Pérez, N. and Chacón, E. (2014). El tamaño del ámbito hogareño y el uso de hábitat de la zorra gris (Urocyon cinereoargenteus) en un bosque templado de Durango, México. Therya, 5(1): 257-269. https://www.redalyc.org/pdf/4023/402333995011.pdf

Silveira, L., Jacomo, A. T. and Diniz-Filho, J. A. F. (2003). Camera trap, line transect census and track surveys: a comparative evaluation. Biological Conservation, 114: 351-355. https://doi.org/10.1016/S0006-3207(03)00063-6

Sinclair, A. R. E. (2003). The role of mammals as ecosystem landscapers. Alces, 39: 161-176. http://flash.lakeheadu. ca/ arodgers/Alces/Vol39/Alces39 161.pdf

Servicio Meteorológico Nacional [SMN]. smn.conagua.gob.mx/es/. [Last Checked: May $15^{\text {th }} 2019$ ].

Spears, B. L., Ballard, W. B., Wallace, M. C., Applegate, R. D. and Gipson, P. S. (2003). Coyote, Canis latrans-Rio Grande turkey, Meleagris gallopavo intermedia, interactions. The Canadian Field-Naturalist, 117(4): 645-647. http:// dx.doi.org/10.22621/cfn.v117i4.816

Small Wild Cat Conservation Foundation [SWCCF]. www.smallcats.org/index. [Last Checked: August $8^{\text {th }} 2016$ ].

Valdéz-Alarcón, M. \& Téllez-Girón, G. (2005). Ardilla. In: Los Mamíferos Silvestres de México. Ceballos G., y G. Oliva, ed. 542-543 pp. Comisión Nacional para el Conocimiento y Uso de la Biodiversidad, Fondo de Cultura Económica. Mexico, Federal District.

Valenzuela-Galvan, D. (2005). Tejón, coatí. In: Los Mamíferos Silvestres de México. Ceballos G., y G. Oliva, ed. 411-412 pp. Comisión Nacional para el Conocimiento y Uso de la Biodiversidad, Fondo de Cultura Económica. Mexico, Federal District.

Verts, B. J., Carraway, L. N. and Kinlaw, A. (2001). Spilogale gracilis. Mammalian Species, 674:1-10. https://doi. org/10.2307/0.674.1

Wassmer, T. \& Refinetti, R. (2016). Daily activity and nest occupation patterns of fox squirrels (Sciurus niger) throughout the year. PloS one, 11:e0151249. https://doi.org/10.1371/journal.pone.0151249

Wright S. J., Zeballos, H., Dominguez, I., Gallardo, M. M., Moreno, M. C. and Ibañez, R. (2000). Poachers alter mammal abundance, seed dispersal and seed predation in a Neotropical forest. Conservation Biology 14(1): 227-239. https://doi.org/10.1046/i.1523-1739.2000.98333.x

Zar, J. H. (2010). Biostatistical analysis, Fifth edition. Nueva Jersey, USA. Pearson Prentice-Hall. 